\title{
PENGARUH FAKTOR FUNDAMENTAL MAKRO DAN MIKRO TERHADAP NILAI PERUSAHAAN (STUDI PADA SAHAM PERUSAHAAN SEKTOR INFRASTRUKTUR DAN SEKTOR KONSTRUKSI YANG TERDAFTAR DI BEI PERIODE 2015 - 2017
}

\author{
Ahmad Fatoni Karim A. ${ }^{1}$, Hermanto ${ }^{2}$, I Nym. Nugraha Ardana P3 \\ ${ }^{1}$ Program Studi Magister Manajemen Fakultas Ekonomi dan Bisnis Unram, \\ Email : afka27araska@gmail.com \\ ${ }^{2}$ Fakultas Ekonomi dan Bisnis Unram. \\ ${ }^{3}$ Fakultas Ekonomi dan Bisnis Unram.
}

\begin{tabular}{|c|c|}
\hline ARTICLE INFO & ABSTRACT \\
\hline $\begin{array}{l}\text { Keywords: } \\
\text { inflation, exchange rate, DER and ROE } \\
\text { How to cite: } \\
\text { Amirullah, Ahmad Fatoni Karim., } \\
\text { Hermanto., Putra, I Nyoman Nugraha A } \\
\text { (2018). Pengaruh Faktor Fundamental } \\
\text { Makro dan Mikro Terhadap Nilai } \\
\text { Perusahaan (Studi pada Saham Perusahaan } \\
\text { Sektor Infrastruktur dan Sektor Konstruksi } \\
\text { yang Terdapftar di BEI Periode 2015-2017). } \\
\text { JMM UNRAM, 7(2), 86 - 102 } \\
\text { DOI: } \\
\text { 10.29303/jmm.v7i2.323 }\end{array}$ & $\begin{array}{l}\text { This study aims to determine the effect of macro and micro } \\
\text { fundamental factors on the company's value, and the object } \\
\text { of research were infrastructure sector companies and } \\
\text { construction sector companies on the Indonesia Stock } \\
\text { Exchange (IDX) in the period } 2015 \text { to } 2017 \text {. Fundamental } \\
\text { macro factors consist of inflation and exchange rates. While } \\
\text { the micro fundamental factors consist of DER and ROE. The } \\
\text { type of research used is associative research. The population } \\
\text { in this study, } 13 \text { companies that were included in the } \\
\text { research criteria, which were engaged in the Infrastructure } \\
\text { and Construction Sector listed on the Indonesia Stock } \\
\text { Exchange (IDX). Data collection techniques are } \\
\text { documentation techniques and then the data are analyzed } \\
\text { using multiple linear regression analysis. The results of this } \\
\text { study indicate that partially, inflation, exchange rates and } \\
\text { DER have no effect on firm value. ROE has a positive and } \\
\text { significant effect on firm value. The variable that has the } \\
\text { most dominant influence on firm value is ROE. This shows } \\
\text { that among the research variables, ROE most influences } \\
\text { investors' decisions to buy the company's shares. } \\
\text { Penelitian ini bertujuan untuk mengetahui pengaruh faktor- } \\
\text { faktor fundamental makro dan mikro terhadap nilai } \\
\text { perusahaan, yang mengambil objek penelitian pada } \\
\text { perusahaan sektor infrastruktur dan sektor konstruksi di } \\
\text { Bursa Efek Indonesia (BEI) pada periode 2015 sampai } 2017 \text {. }\end{array}$ \\
\hline
\end{tabular}




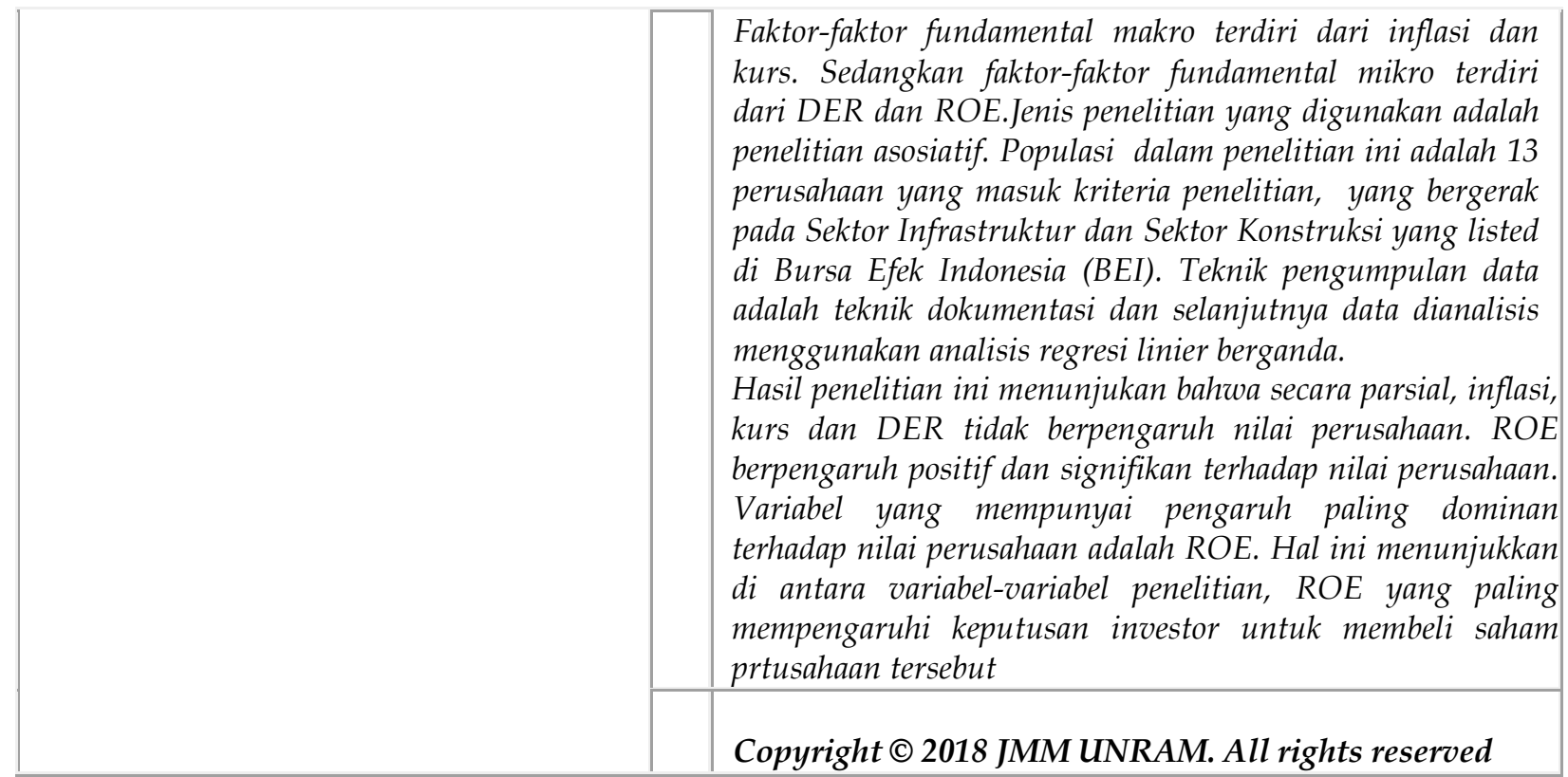

\section{PENDAHULUAN}

Kebijakan dan kinerja perusahaan yang baik akan membuat perusahaan bernilai di hadapan investor. Nilai Perusahaan adalah nilai jual sebuah perusahaan sebagai suatu bisnis yang sedang beroperasi. Adanya kelebihan nilai jual diatas nilai likuidasi adalah nilai dari organisasi manajemen yang menjalankan perusahaan itu (Sartono, 2010). Nilai perusahaan dapat dilihat dari harga sahamnya. Harga saham terbentuk atas permintaan dan penawaran investor, sehingga harga saham di pasar modal merupakan penilaian investor terhadap kinerja perusahaan secara keseluruhan yang ditandai dengan fundamental perusahaan yang baik.

Penelitian ini menggunakan aspek fundamental sebagai dasar penilaian investor dalam mengambil keputusan melakukan investasi saham di pasar modal. faktor fundamental terdiri dari makro dan mikro. Faktor fundamental makro merupakan faktor yang tidak bisa dikendalikan (uncontrollable) oleh perusahaan, sebaliknya faktor fundamental mikro merupakan faktor yang dapat dikendalikan (controllable) oleh perusahaan. Faktor fundamental makro yang berada diluar kendali perusahaan, seperti inflasi, tingkat bunga, kurs, jumlah uang yang beredar dan pertumbuhan ekonomi, akan dapat mempengaruhi perilaku investor dalam mengambil keputusan investasi di pasar modal. Perubahanperubahan yang terjadi pada faktor ini dapat mengakibatkan perubahan-perubahan di pasar modal, yaitu meningkat atau menurunnya harga saham. Sedangkan faktor fundamental mikro sering disebut dengan faktor fundamental perusahaan, faktor ini bersifat controllable sehingga dapat dikendalikan perusahaan. faktor fundamental mikro dapat dikelompokkan dalam faktor kebijakan perusahaan dan faktor kinerja perusahaan. Faktor kinerja perusahaan yang berhubungan dengan kondisi perusahaan pada umumnya ditunjukkan dalam laporan keuangan yang dapat mencerminkan kinerja keuangan suatu perusahaan. Dari laporan keuangan dapat menunjukan rasio keuangan, arus kas dan ukuran-ukuran kinerja lainnya yang dapat memproyeksikan nilai perusahaan tersebut. Faktor fundamental perusahaan yang sering digunakan untuk memprediksi harga saham atau return saham adalah rasio keuangan 
dan rasio pasar (Ismanidar, 2017). Rasio keuangan terdiri dari rasio likuiditas, rasio solvabilitas, rasio aktivitas, rasio rentabilitas/ proftabilitas dan rasio pasar.

Kebijakan dan kinerja perusahaan yang baik di hadapan investor dapat dilihat dari kemampuan perusahaan dalam memaksimalkan dana perusahaan dalam menghasilkan laba. Pendanaan dapat dilakukan dengan menggunakan berbagai sumber dana, baik yang berasal dari luar maupun dalam perusahaan, hal tersebut menyebabkan perusahaan memiliki kewajiban (utang) pada pihak sumber dana, baik dari dalam perusahaan maupun luar perusahaan, sehingga manajemen perusahaan harus mampu memenuhi target yang telah ditetapkan, berupa keuntungan yang maksimal dari dana yang di peroleh. Selain itu manajemen perusahaan harus dapat memahami dan meramalkan kondisi ekonomi makro Indonesia agar dapat meminimalkan risiko. Merujuk dari objek penelitian yaitu sektor infrastruktur dan sektor konstruksi, dimana dalam operasinya menggunakan sumber dana dari dalam perusahaan maupun luar perusahaan, sehingga penelitian ini ingin melihat jumlah dana yang disediakan peminjam (kreditor) dengan pemilik perusahaan yang dapat diproksikan dengan Debt to Equity Ratio (DER), sedangkan kemampuan perusahaan dalam memaksimalkan sumber dana diperoksikan dengan Return On Equity (ROE), hal ini di karenakan penelitian ini ingin melihat efesiensi penggunaan modal sendiri perusahaan dalam menghasilkan laba.

Kondisi ekonomi makro Indonesia dalam 4 tahun terakhir yang menarik untuk di tinjau pengaruhnya terhadap nilai perusahaan yaitu kurs dan inflasi. Menguatnya kurs rupiah terhadap mata uang asing merupakan sinyal positif bagi perekonomian yang mengalami inflasi (Tandelilin, 2010), yang berarti seharusnya saat kurs rupiah menguat terhadap dollar, inflasi dapat turun begitupula sebaliknya, sedangkan pada tabel 1, menunjukan kurs rupiah terhadap dollar berfluktuasi cenderung meningkat, sedangkan inflasi berfluktuasi cenderung menurun.

Tabel 1

Perkembangan Indikator Ekonomi Indonesia

\begin{tabular}{|l|l|l|l|l|l|}
\hline No & Indikator & 2014 & 2015 & 2016 & 2017 \\
\hline 1 & Inflasi (\%) & 8,36 & 3,35 & 3,02 & 3,61 \\
2 & Kurs (Rp) & 11937,73 & 13458,93 & 13373,89 & 13451,22 \\
\hline
\end{tabular}

Sumber : BPS dan BI (data diolah April 2018).

Hasil penelitian tentang pengaruh inflasi dan kurs terhadap nilai perusaahaan yang dilakukan oleh Elzadora (2009), Arvianto, dkk (2014) Hardaningtyas (2014) menunjukan bahwa inflasi dan kurs berpengaruh positif dan signifikan, berbeda dengan penelitian yang di lakukan oleh Opod (2015) Novitasari (2017) dengan hasil penelitian yang menyimpulkan bahwa inflasi dan kurs tidak berpengaruh signifikan. Begitu juga penelitian yang dilakukan Paizal (2017) menghasilkan inflasi dan kurs tidak berpengaruh.

Variabel faktor fundamental mikro yang digunakan dalam penelitian ini adalah Debt to Equity Ratio (DER), dan Return On Equity (ROE). DER digunakan untuk mengukur seberapa besar kemampuan perusahaan melunasi total hutang jangka panjang dengan modal yang mereka miliki. Semakin kecil hasilnya semakin baik karena aman bagi kreditor saat liquidasi. Tak jadi soal jika laba sedikit asal perusahaan tetap mampu membayar kewajiban jangka panjangnya dengan modal yang dimiliki (Arifin, 2007). Rasio ini menunjukkan perbandingan antara pembiayaan dan pendanaan melalui hutang dan pendanaan melalui ekuitas. 
Hasil penelitian tentang pengaruh DER terhadap nilai perusahaan yang dilakukan oleh Uli (2009), Sinaga \& Triaryati (2015) menujukan bahwa DER tidak berpengaruh terhadap nilai perusahaan. Namun berbeda dengan penelitian yang di lakukan oleh Elzadora (2009), Opod (2015) mendapati bahwa DER berpengaruh signifikan terhadap nilai perusahaan. Selaras dengan hasil penelitian Rachman \& Sutrisno (2013), Hardaningtyas (2014), Paizal (2017) yang menujukan bahwa DER secara parsial memiliki pengaruh positif dan signifikan terhadap nilai perusahaan.

Nilai perusahaan dapat pula dipengaruhi oleh besar kecilnya profitabilitas yang dihasilkan oleh perusahaan. Rasio profitabilitas merupakan rasio untuk menilai kemampuan perusahaan dalam mencari keuntungan (Kasmir, 2013). Profitabilitas yang tinggi mencerminkan kemampuan manajemen perusahaan yang baik dan efektif dalam menghasilkan keuntungan yang tinggi bagi para pemegang saham. Profitabilitas tersebut antara lain dapat dilihat menggunakan ROE yang merupakan financial performance dalam kinerja perusahaan. ROE digunakan untuk mengukur sejauh mana suatu perusahaan mempergunakan sumber daya yang dimiliki untuk mampu memberikan laba atas ekuitas (Fahmi, 2013). Dengan kinerja perusahaan yang ditunjukan dengan financial performance yang baik akan meningkatkan pula nilai perusahaan tersebut, hal ini di karenakan semakin diminatinya saham perusahaan tersebut oleh investor. Hasil penelitian yang dilakukan oleh Uli (2009) menujukan bahwa ROE tidak berpengaruh terhadap nilai perusahaan Namun berbeda dengan penelitian yang di lakukan oleh Elzadora (2009), Opod (2015) mendapati bahwa ROE berpengaruh signifikan terhadap nilai perusahaan. Selaras dengan hasil Sinaga \& Triaryati (2015) Paizal (2017) mendapatkan ROE berpengaruh positif signifikan terhadap nilai perusahaan. Sedangkan Hardaningtyas (2014) medapatkan ROE mempunyai pengaruh tetapi tidak signifikan terhadap nilai perusahaan.

Pengambilan objek pada penelitian ini di motivasi oleh fenomena yang ada, dimana pemerintah indoneisa saat ini melakukan pembangunan infrastruktur untuk dapat mengejar ketertinggalan dari negara lain. Hal ini dapat terlihat dari peningkatan anggaran di sektor infrastruktur yang dilakukan oleh pemerintah seperti terlihat pada grafik 1 .

Gerafik 1

Anggaran Infrastruktur 2014-2017

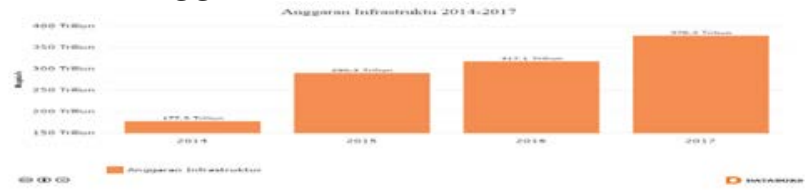

Sumber : databoks.katadata.co.id

Bahkan dalam Anggaran Pendapatan dan Belanja Negara (APBN) 2018, pemerintah menganggarkan belanja infrastruktur sebesar Rp 410,7 triliun yang akan dipakai untuk pembangunan berbagai infrastruktur di seluruh Indonesia diantaranya $865 \mathrm{~km}$ jalan baru, 25 $\mathrm{km}$ jalan tol, $8.695 \mathrm{~km}$ jembatan, pembangunan bandar udara di 8 lokasi dan juga untuk pembangunan jalur kereta api ( economy.okezone.com). Keberadaan sektor infrastruktur dan sektor kontruksi di Indonesia memiliki kontribusi besar dalam menghasilkan GDP. Sektor kotruksi menduduki peringkat ketiga sebagai pendorong pertumbuhan ekonomi di Indonesia sepanjang 2016, dengan kontribusi 0,51 persen (www.bps.go.id). Hal inilah menyebabkan sektor infrastruktur dan kontruksi saat ini sangat menarik untuk di teliti. Kedua sektor ini dapat keuntungan lebih dari kebijakan yang dilakukan oleh pemerintah saat ini. Selain itu pemerintah dan DPR baru saja merampungkan Undang-Undang (UU) Nomor 2 Tahun 2017 
tentang Jasa Konstruksi. Aturan ini menggantikan UU Jasa Konstruksi Nomor 18 tahun 1999( finance.detik.com). Dalam UU baru ini diatur dari hulu sampai hilir tentang jasa konstruksi baik mengenai rantai pasok, delivery system dalam sistem pengadaan barang dan jasa serta mutu konstruksi mutu, serta kebutuhan dalam penyelesaian sengketa konstruksi. Sehingga dengan fokus pembanguna infrastruktur yang dilakukan oleh pemerintah Indonesia saat ini dan regulasi baru tentang jasa konstruksi dapat menjadai stimulus positif bagi investor yang akan membuat investor menaruh perhatian lebih pada sektor infrastruktur dan kontruksi.

Meninjau dari peneltian terdahulu dan fenomena saat ini, peneliti ingin melihat pengaruh dari faktor fundamental makro dan mikro terhadap nilai perusahaan pada saham perusahaan sektor infrastruktur dan sektor kontruksi yang terdaftar di Bursa Efek Indonesia periode 2015 sampai 2017.

\section{TINJAUAN PUSTAKA}

\subsection{Trade Off Theory}

Trade Off Theory mengasumsikan bahwa struktur modal perusahaan merupakan hasil trade off dari keuntungan pajak dengan menggunakan hutang dengan biaya yang akan timbul sebagai akibat dari penggunaan hutang tersebut (Hartono, 2013). Esensi trade off theory dalam struktur modal adalah menyeimbangkan manfaat dan pengorbanan yang timbul sebagai akibat penggunaan hutang. Jika manfaat lebih besar maka diperkenankan menggunakan tambahan hutang akan tetapi jika pengorbanan penggunaan hutang jauh lebih besar maka tambahan hutang tidak di perbolehkan.

\subsection{Pecking Order Theory}

Teori ini menyatakan bahwa ada semacam tata urutan (pecking order) bagi peruahaan dalam menggunakan modal. Teori tersebut juga menjelaskan bahwa peusahaan lebih mengutamakan pendanaan ekuitas internal (penggunaan laba ditahan) daripada pendanaan ekuitas external (menerbitkan saham baru).

\subsection{Agency Theory}

Dalam teori keagenan struktur modal disusun untuk mengurangi konflik antar berbagai kelompok kepentingan. Konflik pemegang saham dengan manajer sebenarnya adalah konsep free cash flow. Tetapi ada kecenderungan bahwa manajer ingin menahan sumber daya sehingga mempunyai kontrol atas sumber daya tersebut. Hutang dapat dianggap sebagai cara untuk mengurangi konflik keagenan terkait free cash flow. Jika perusahaan menggunakan hutang maka manajer akan dipaksa untuk mengeluarkan kas dari perusahaan untuk membayar bunga.

\subsection{Signal Theory}

Teori ini menjelaskan bahwa perusahaan yang meningkatkan hutang dapat dipandang sebagai perusahaan yang yakin dengan prospek perusahaan yang akan datang. Peningkatan hutang juga diartikan pihak luar tentang kemampuan perusahaan membayar kewajibannya di masa yang akan datang atau risiko bisnis yang rendah, sehingga penambahan hutang akan memberikan sinyal positif (Brigham dan Houston, 2001) 


\subsection{Nilai Perusahaan}

Nilai perusahaan merupakan kondisi tertentu yang telah dicapai oleh suatu perusahaan sebagai gambaran dari kepercayaan masyarakat terhadap perusahaan setelah melalui suatu proses kegiatan selama beberapa tahun, yaitu sejak perusahaan tersebut didirikan sampai dengan saat ini (Sudiyanto, 2010). Beberapa indikator untuk mengukur nilai perusahaan antara lain : Price earning ratio, Tobin's $Q$ dan Price book value.

\subsection{Analisis Fundamental}

Analisis fundamental adalah analisis untuk mengetahui kondisi emiten, pertumbuhan industri dan aspek makro suatu negara (Susilo, 2009).

\subsection{Faktor fundamental}

Faktor-faktor fundamental sangat luas dan kompleks, tidak hanya meliputi kondisikondisi internal perusahaan tetapi juga kondisi eksternal perusahaan. Sehingga faktor fundamental dapat dibedakan menjadi faktor fundamental makro dan faktor fundamental mikro.

\subsection{Kerangka Konseptual}

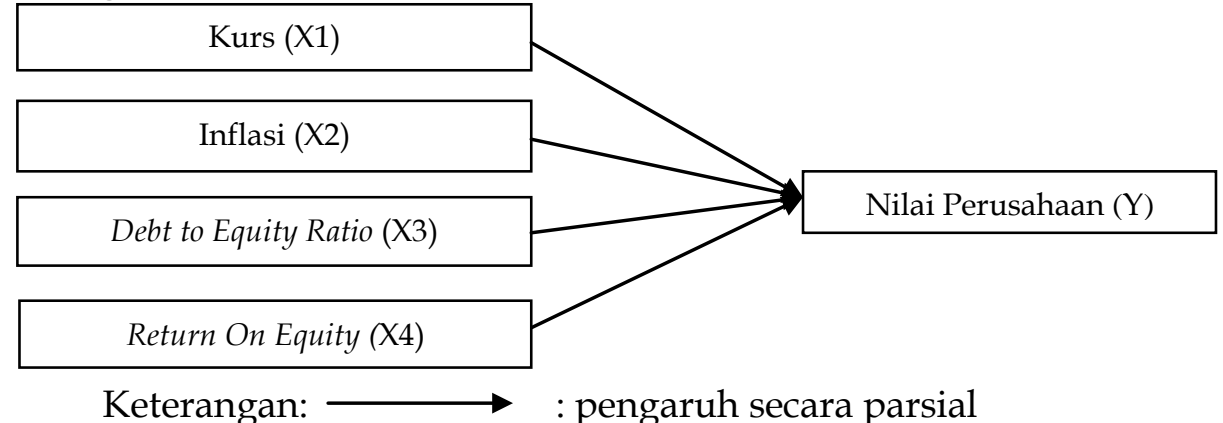

Keterangan: $\longrightarrow$ : pengaruh secara parsial

\subsection{HIPOTESIS}

Hipotesis yang diajukan dalam penelitian ini adalah sebagai berikut :

H1 : Diduga terdapat pengaruh inflasi yang signifikan terhadap nilai perusahaan pada perusahaan sektor infrastruktur dan sektor kontruksi yang terdaftar di Bursa Efek Indonesia periode 2015 sampai 2017.

H2 : Diduga terdapat pengaruh kurs(nilai tukar) yang signifikan terhadap nilai perusahaan pada perusahaan sektor infrastruktur dan sektor kontruksi yang terdaftar di Bursa Efek Indonesia periode 2015 sampai 2017

H3 : Diduga terdapat pengaruh Debt to Equity Ratio (DER) yang positif signifikan terhadap nilai perusahaan pada perusahaan sektor infrastruktur dan sektor kontruksi yang terdaftar di Bursa Efek Indonesia periode 2015 sampai 2017.

H4 : Diduga terdapat pengaruh Return On Equity (ROE) yang positif signifikan terhadap nilai perusahaan pada perusahaan sektor infrastruktur dan sektor kontruksi yang terdaftar di Bursa Efek Indonesia periode 2015 sampai 2017.

H5 : Diduga variabel ROE yang mempunyai pengaruh yang paling dominan terhadap nilai perusahaan pada sektor infrastruktur dan sektor kontruksi yang terdaftar di Bursa Efek Indonesia periode 2015 sampai 2017. 


\section{METODOLOGI PENELITIAN}

\subsection{Jenis Penelitian}

Jenis penelitian penelitian yang dilakukan adalah penelitian asosiatif yaitu penelitian yang mencari pengaruh antara dua variabel atau lebih dengan pendekatan kuantitatif yaitu penelitian yang data penelitian berupa angka - angka dan analisis yang digunakan menggunakan statistik (Sugiyono, 2013). Penelitian ini mengambil objek saham-saham yang termasuk ke dalam sektor Infrastruktur dan sektor Kontruksi pada Bursa Efek Indonesia (BEI) tahun 2015 sampai 2017. Metode pengumpulan data yang digunakan dalam penelitian ini adalah metode sample survey. Dalam penelitian ini yang menjadi populasi adalah 13 perusahaan yang bergerak pada Sektor Infrastruktur dan Sektor Konstruksi yang listed di Bursa Efek Indonesia (BEI). Data mengenai perusahaan diperoleh dari daftar perusahaan yang telah dipublikasikan di www.idx.co.id. Teknik pengambilan sampel menggunakan purposive sampling.

Berdasarkan perumusan masalah, maka dapat diidentifikasi variabel-variabel sebagai berikut: Fundamental Makro : Inflasi dan Kurs, Fundamental Mikro : Debt to Equity Ratio (DER) dan Return On Equity (ROE) dan Nilai Perusahaan di proksikan dengan Tobin's Q.

\subsection{Definisi Operasional Variabel}

Berdasarkan identifikasi variabel di atas, maka dapat dijelaskan variabel-variabel tersebut sebagai berikut:

a) Inflasi adalah kondisi dimana harga barang mengalami kenaikan dan nilai mata uang mengalami pelemahan yang di presentasikan oleh Bank Indonesia periode 2015-2017. Inflasi dinyatakan dalam bentuk nilai beta inflasi masing masing perusahaan.

b) Kurs Valuta Asing adalah harga mata uang suatu negara terhadap mata uang asing lainnya, dalam hal ini harga mata uang dollar Amerika serikat terhadap rupiah. Kurs dinyatakan dalam bentuk nilai beta kurs masing masing perusahaan.

c) Debt to Equity Ratio (DER) adalah rasio antara hutang jangka panjang dengan total ekuitas emiten saham sektor infrastruktur dan sektor konstruksi periode 2015-2017. DER dinyatakan dalam satuan persentase (\%).

d) Return On Equity (ROE) adalah rasio antara laba bersih setelah pajak dengan total ekuitas emiten saham sektor infrastruktur dan sektor konstruksi periode 2015-2017. ROE dinyatakan dalam satuan persentase (\%).

e) Nilai Perusahaan adalah persepsi investor terhadap tingkat keberhasilan perusahaan yang sering dikaitkan dengan harga saham. Harga saham yang tinggi menunjukan nilai perusahaan yang tinggi pula. Nilai perusahaan pada penelitian ini dinyatakan dengan Tobin's $Q$ indikator.Jika nilai Tobin's $Q$ perusahaan lebih dari satu, berarti nilai pasar perusahaan tersebut lebih besar daripada aktiva perusahaan yang tercatat. Tobin's Q dinyatakan dalam satuan kali.

\subsection{Prosedur Analisis Data}

Prosedur anaisis data yaitu Menentukan Sensitifitas Kurs dan Inflasi. Penentuan sensitifitas tingkat inflasi dan kurs digunakan untuk melihat intensitas dari dampak inflasi dan kurs pada masing masing perusahaan pada periode penelitian, Uji Asumsi Dasar digunakan untuk melihat apakah data berdistribusi normal atau atau tidak, Melakukan Uji Asumsi Klasik digunakan untuk mendeteksi adanya gejala multikolonieritas, untuk mengetahui ada 
tidaknya heteroskedastisitas, dan untuk mendeteksi adanya autokorelasi, Analisis Statistik Deskriptif Statistik dalam penelitian ini merupakan proses transformasi data penelitian dalam bentuk tabulasi sehingga mudah dipahami dan diinterpretasikan, Analisis Regresi Berganda, analisis ini dipilih karena penelitian ini dirancang untuk meneliti faktor-faktor yang berpengaruh pada variabel independen terhadap variabel dependen, dimana variabel independen yang digunakan dalam penelitian ini lebih dari satu, Uji Kelayakan Model (UjiF) di gunakan untuk menilai kelayakan model regresi yang telah terbentuk, Melakukan Uji Parsial (uji $\mathbf{t}$ test) digunakan untuk menguji koefisien regresi secara parsial dari variabel bebas terhadap variabel terikat, Koefisien Determinasi (Adjusted R2) bertujuan untuk mengukur seberapa jauh kemampuan model dalam menerangkan variasi variabel dependen, Koefisien Determinasi Parsial digunakan untuk melihat dominansi variabel.

\section{HASIL DAN PEMBAHASAN}

Hasil regresi time series untuk mendapatkan nilai beta inflasi dan kurs masing masing perusahaan adalah sebagai berikut :

Tabel 2. Nilai Beta Inflasi dan Kurs

\begin{tabular}{|l|l|l|l|l|l|l|}
\hline & & INFLASI & & & KURS & \\
\hline & 2015 & 2016 & 2017 & 2015 & 2016 & 2017 \\
\hline ADHI & -0.515 & 6.529 & -2.187 & 0.00001911 & 0.00000000 & -0.00001740 \\
\hline ASRI & -1.705 & 5.279 & -4.199 & -0.00008982 & -0.00004597 & -0.00008674 \\
\hline BSDE & -2.989 & -0.857 & -0.225 & -0.00004877 & -0.00005382 & -0.00001928 \\
\hline GIAA & -2.102 & 12.415 & 4.609 & -0.00004569 & 0.00000000 & 0.000 \\
\hline JSMR & -4.002 & 2.409 & 6.522 & 0.0000006147 & 0.00000000 & 0.00007571 \\
\hline LPKR & 1.931 & 3.443 & 6.481 & -0.00001510 & 0.00008599 & -0.001 \\
\hline PGAS & -2.790 & -0.389 & -3.243 & 0.00001173 & 0.00000000 & 0.001 \\
\hline PTPP & -1.182 & -0.837 & 0.865 & -0.00001506 & -0.00002980 & 0.000 \\
\hline PWON & -4.368 & 1.690 & -0.698 & 0.00001927 & 0.00000000 & 0.000 \\
\hline SMRA & -3.643 & 0.885 & 3.362 & 0.00000000 & -0.00003691 & -0.00004582 \\
\hline TLKM & -2.204 & -0.671 & 3.299 & -0.000006454 & 0.00005074 & 0.000 \\
\hline WIKA & 0.715 & 0.119 & -1.074 & 0.00001545 & 0.00008411 & -0.00004281 \\
\hline WSKT & -0.531 & 4.619 & -3.164 & -0.00006394 & 0.00003644 & 0.001 \\
\hline
\end{tabular}

Setelah didapatkan nilai beta saham inflasi dan kurs untuk masing-masing perusahaan, baru dilanjutkan dengan meregresikan nilai beta saham tersebut dengan model yang sudah di tentukan.

\subsection{Uji Asumsi Dasar}

- Uji Normalitas

Hasil pengujian normalitas data dalam penelitian ini dapat dilihat pada tabel 3. 


\section{NATIONALY ACCREDTTED JOURNAL - DERREE NO. 21/E/RPT/2018}

Tabel 3. Hasil Uji Normalitas

One-Sample Kolmogorov-Smirnov Test

\begin{tabular}{lll} 
& & $\begin{array}{l}\text { Unstandardized } \\
\text { Residual }\end{array}$ \\
\hline $\mathrm{N}$ & & 39 \\
\hline Normal Parametersa, $\mathrm{b}$ & Mean & .0000000 \\
\cline { 2 - 3 } & Std. Deviation & .37102248 \\
\hline Most Extreme Differences & Absolute & .068 \\
\cline { 2 - 3 } & Positive & .068 \\
\cline { 2 - 3 } & Negative & -.066 \\
\hline Test Statistic & & .068 \\
\hline Asymp. Sig. (2-tailed) & & $.200 \mathrm{c}, \mathrm{d}$ \\
\hline a. Test distribution is Normal. &
\end{tabular}

Berdasarkan hasil uji normalitas dengan menggunakan uji One-Sample KolmogorovSmirnov, terlihat bahwa nilai signifikansi pada 0,200 diatas 0,05. Hal ini menunjukkan nilai residual terdistribusi secara normal atau memenuhi asumsi klasik normalitas. Dari hasil tersebut dapat disimpulkan bahwa data dari variabel inflasi, kurs, DER dan ROE sudah berdistribusi normal.

\subsection{Uji Asumsi Klasik}

\subsubsection{Uji Multikolinieritas} berikut ini:

Hasil pengujian multikolinieritas data dalam penelitian ini dapat dilihat pada tabel 4

\begin{tabular}{|c|c|c|c|c|c|c|c|c|}
\hline \multicolumn{9}{|c|}{ Coefficientsa } \\
\hline \multirow[b]{2}{*}{ Model } & & \multicolumn{2}{|c|}{ Unstandardized Coefficients } & \multirow{2}{*}{$\begin{array}{l}\text { Standardized } \\
\text { Coefficients } \\
\text { Beta }\end{array}$} & \multirow[b]{2}{*}{$t$} & \multirow[b]{2}{*}{ Sig. } & \multicolumn{2}{|c|}{ Collinearity Statistics } \\
\hline & & B & Std. Error & & & & Tolerance & VIF \\
\hline 1 & (Constant) & 1.147 & .186 & & 6.173 & .000 & & \\
\hline & Inflasi & .021 & .020 & .162 & 1.071 & .292 & .745 & 1.342 \\
\hline & Kurs & 193.566 & 245.371 & .113 & .789 & .436 & .838 & 1.193 \\
\hline & $\overline{\mathrm{DER}}$ & -.001 & .001 & -.248 & -1.754 & .088 & .858 & 1.166 \\
\hline & $\mathrm{ROE}$ & .034 & .008 & .602 & 4.305 & .000 & .877 & 1.140 \\
\hline
\end{tabular}

a. Dependent Variable: TobinsQ

Hasil uji multikolonieritas pada tabel 4 terlihat bahwa semua variabel independen yang memiliki nilai tolerance diatas 0,10 dan hasil perhitungan Variance Inflation Factor (VIF) juga menunjukkan bahwa semua variabel independen yang memiliki nilai VIF di bawah 10. Maka dapat disimpulkan bahwa persamaan model regresi yang diajukan bebas dari multikolonieritas.

\subsubsection{Uji Autokolerasi}

Hasil keputusan didasakan besaran profitabilitas, jika profitabilitas $>0,05$ maka residual acak, jika profitabilitas $<0,05$ maka residual tidak random. 
Tabel 5 Hasil Uji Autokorelasi Run Test

Runs Test

\begin{tabular}{ll} 
& $\begin{array}{l}\text { Unstandardized } \\
\text { Residual }\end{array}$ \\
\hline Test Valuea & -.00944 \\
\hline Cases < Test Value & 19 \\
\hline Cases $>=$ Test Value & 20 \\
\hline Total Cases & 39 \\
\hline Number of Runs & 17 \\
\hline$Z$ & -.970 \\
\hline Asymp. Sig. (2-tailed) & .332
\end{tabular}

Hasil run test menunjukan asym.sig adalah 0.332 atau probabilitas di atas $0,05(0,332>$ 0,05) , maka dapat disimpulkan bahwa data yang digunakan random, yang berarti tidak terdapat autokorelasi pada data sampel.

\subsubsection{Uji Heteroskedasitas}

Hasil pengujian ditunjukan pada grafikl berikut :

Grafik 2. Uji Heteroskedasitas

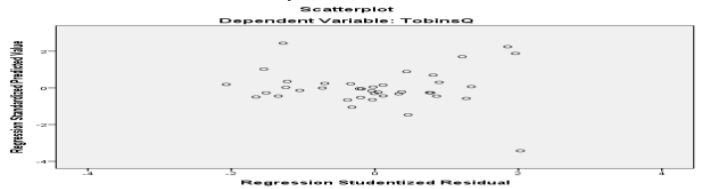

Heteroskedastisitas tidak terjadi jika data berpencar di sekitar angka nol (0 pada sumbu Y) dan tidak membentuk suatu pola atau tren garis tertentu. Grafik 2 menunjukkan bahwa data sampel berupa titik-titik menyebar secara acak, dan tersebar baik berada di atas maupun di bawah angka 0 (nol) pada sumbu Y. Hal ini menunjukkan tidak terdapat heteroskedastisitas dalam model regresi yang digunakan.

\subsection{Analisis Regresi Linier Berganda}

Hasil regresi linier berganda dapat dimasukkan dalam persamaan menjadi :

Tabel 6 Hasil Analisis Regresi Linier Berganda

Coefficientsa

\begin{tabular}{|c|c|c|c|c|c|c|}
\hline \multirow[b]{2}{*}{ Model } & & \multicolumn{2}{|c|}{ Unstandardized Coefficients } & \multirow{2}{*}{$\begin{array}{l}\text { Standardized } \\
\text { Coefficients } \\
\text { Beta }\end{array}$} & \multirow[b]{2}{*}{$t$} & \multirow[b]{2}{*}{ Sig. } \\
\hline & & B & Std. Error & & & \\
\hline$\overline{1}$ & (Constant) & 1.147 & .186 & & 6.173 & .000 \\
\hline & Inflasi & .021 & .020 & .162 & 1.071 & .292 \\
\hline & Kurs & 193.566 & 245.371 & .113 & .789 & .436 \\
\hline & DER & -.001 & .001 & -.248 & -1.754 & .088 \\
\hline & $\mathrm{ROE}$ & .034 & .008 & .602 & 4.305 & .000 \\
\hline
\end{tabular}

a. Dependent Variable: TobinsQ

Berdasarkan hasil uji statistik t pada tabel 6, maka dapat dijelaskan sebagai berikut :

Pengujian Hipotesis 1 :

Ha1 : Diduga terdapat pengaruh inflasi yang signifikan terhadap nilai perusahaan pada perusahaan sektor infrastruktur dan sektor kontruksi yang terdaftar di Bursa Efek Indonesia periode 2015 sampai 2017.

Inflasi mempunyai nilai thitung $=1,071$, karena thitung $>$ ttabel yaitu thitung $=1,071>$ ttabel $=$ 2,03224 dengan tingkat signifikan sebesar 0,292 yakni di atas 0,05 yang berarti bahwa 
variabel inflasi tidak berpengaruh dan tidak signifikan terhadap nilai perusahaan, sehingga hipotesis pertama yang diajukan ditolak.

Pengujian Hipotesis 2 :

Ha2 : Diduga terdapat pengaruh kurs(nilai tukar) yang signifikan terhadap nilai perusahaan pada perusahaan sektor infrastruktur dan sektor kontruksi yang terdaftar di Bursa Efek Indonesia periode 2015 sampai 2017

Kurs valas mempunyai nilai thitung $=0,789$, karena thitung $>$ ttabel yaitu thitung $=$ $0,789>$ ttabel $=2,03224$ dengan tingkat signifikan sebesar 0,436 yakni di atas 0,05 yang berarti bahwa variabel kurs tidak berpengaruh dan tidak signifikan terhadap nilai perusahaan, sehingga hipotesis kedua yang diajukan ditolak.

Pengujian Hipotesis 3 :

Ha3 : Diduga terdapat pengaruh Debt to Equity Ratio (DER) yang positif signifikan terhadap nilai perusahaan pada perusahaan sektor infrastruktur dan sektor kontruksi yang terdaftar di Bursa Efek Indonesia periode 2015 sampai 2017.

DER mempunyai nilai thitung $=-1,754$ karena thitung $<$ ttabel yaitu thitung $=-1,754<$ ttabel = 2,03224 dengan tingkat signifikan sebesar 0,088 yakni diatas 0,05 yang berarti bahwa variabel DER berpengaruh negatif dan tidak signifikan terhadap nilai perusahaan, sehingga hipotesis yang diajukan ditolak.

Pengujian Hipotesis 4 :

Ha4 : Diduga terdapat pengaruh Return On Equity (ROE) yang positif signifikan terhadap nilai perusahaan pada perusahaan sektor infrastruktur dan sektor kontruksi yang terdaftar di Bursa Efek Indonesia periode 2015 sampai 2017.

ROE mempunyai nilai thitung $=4,305$, karena thitung $>$ ttabel yaitu thitung $=4,305>$ ttabel $=2,03224$ dengan tingkat signifikan sebesar 0,000 yakni di bawah 0,05 yang berarti bahwa variabel ROE berpengaruh positif dan signifikan terhadap nilai perusahaan, sehingga hipotesis keempat yang diajukan diterima.

\subsection{Koefisien Determinasi Parsial Atau r2 Parsial}

Tabel 7 Koefisien Korelasi Parsial (r)

Coefficientsa

\begin{tabular}{lllll} 
& \multicolumn{3}{c}{} & \multicolumn{2}{c}{ Correlations } \\
Model & & Zero-order & Partial & Part \\
\hline 1 & & & & \\
\cline { 2 - 5 } & (Constant) & & .181 & .140 \\
\hline & Inflasi & -.134 & .134 & .103 \\
\cline { 2 - 5 } Kurs & .053 & -.288 & -.230 \\
\cline { 2 - 5 } DER & -.296 & .594 & .563 \\
\hline ROE & .599 & & \\
\hline
\end{tabular}

a. Dependent Variable: TobinsQ

H5 : Diduga variabel ROE yang mempunyai pengaruh yang paling dominan terhadap nilai perusahaan pada sektor infrastruktur dan sektor kontruksi yang terdaftar di Bursa Efek Indonesia periode 2015 sampai 2017

Dari hasil perhitungan koefisien determinasi parsial di atas, dapat dilihat bahwa variabel yang nilainya paling tinggi adalah variabel ROE yaitu sebesar $0,352836=$ $35,2836 \%$. Berarti variabel ROE yang mempunyai pengaruh paling dominan terhadap nilai perusahaan, sehingga hipotesis yang diajukan diterima. 


\subsection{Pembahasan}

Berdasarkan perhitungan analisis regresi linier berganda diperoleh persamaanpersamaan:

Tobin's Q = 1,147+0.021 Inflasi + 193.566 Kurs - 0,001 DER + 0,034 ROE

Nilai konstanta menunjukkan angka sebesar 1,147 yang berarti bahwa apabila nilai variabel inflasi, kurs, DER dan ROE, sama dengan nol, maka nilai perusahaan bernilai 1,147 kali. Nilai b1, b2 dan b4 pada perhitungan yang bernilai positif menunjukkan bahwa antara inflasi $(\mathrm{X} 1)$, kurs $(\mathrm{X} 2)$ dan $\mathrm{ROE}(\mathrm{X} 4)$, terhadap nilai perusahaan $(\mathrm{Y})$ terdapat pengaruh yang positif, yang berarti bila inflasi, kurs dan ROE mengalami peningkatan, maka nilai perusahaan akan mengalami peningkatan. Begitupula sebaliknya, apabila kurs dan ROE mengalami penurunan, maka nilai perusahaan akan mengalami penurunan. Sedangkan nilai b3 pada perhitungan yang bernilai negatif menunjukkan bahwa DER (X3) terhadap nilai perusahaan (Y) terdapat pengaruh yang negatif atau terbalik, yang berarti apabila inflasi dan DER mengalami peningkatan, maka nilai perusahaan akan mengalami penurunan. Sebaliknya, apabila DER mengalami penurunan, maka nilai perusahaan akan mengalami peningkatan.

Hasil penelitian terhadap masing-masing variabel diuraikan sebagai berikut :

\section{Pengaruh Inflasi terhadap Nilai Perusahaan}

Hasil penelitian ini menunjukkan bahwa variabel inflasi tidak berpengaruh terhadap nilai perusahaan. Hal ini menunjukkan bahwa tingkat inflasi di Indonesia selama periode penelitian tidak memberikan pengaruh terhadap nilai perusahaan, berarti investor pada periode penelitian tidak mempermasalahkan inflasi saat melakukan investasi. Merujuk pada tingkat inflasi 2015 sampai 2017 yang termasuk dalam katagori inflasi ringan, dimana kondisi inflasi $<10 \%$ pertahun dianggap banyak pihak memberi kenyamanan bagi banyak kalangan bisnis terutama manajemen perusahaan dan khususnya investor, hal tersebutlah mengidentifikasikan penyebab tingkat inflasi pada periode 2015 sampai 2017 tidak memberikan dampak pada nilai perusahaan sektor infrastruktur dan sektor konstruksi di Indonesia.

Penelitian ini selaras dengan penelitian Opod (2015) Sinaga \& Triaryati (2015) Novitasari (2017) Paizal (2017) dengan hasil penelitian yang menyimpulkan bahwa inflasi tidak berpengaruh signifikan terhadap nilai perusahaan. Dengan demikian hipotesis 1 (H1) yang menyatakan bahwa "terdapat pengaruh inflasi yang signifikan terhadap nilai perusahaan" ditolak.

\section{Pengaruh Kurs terhadap Nilai Perusahaan}

Hasil penelitian ini menunjukkan bahwa variabel kurs tidak berpengaruh terhadap nilai perusahaan. Hal ini menunjukkan bahwa apresiasi atau depresiasinya Rp/US\$ tidak berpengaruh terhadap nilai perusahaan. Hal ini menujukan bahwa investor tidak mempertimbangkan kurs saat berinvestasi di pasar modal Indonesia. Merujuk pada tingkat pertumbuhan kurs rupiah terhadap dollar selama periode 2015 sampai 2017 yang berfeluktuasi cenderung meningkat, tetapi hasil penelitian tidak mempengaruhi nilai perusahaan, menunjukan bahwa investor mengganggap pertumbuhan kurs rupiah terhadap dollar masih di anggap wajar, dikarenakan hal tersebut tidak hanya terjadi di Indonesia, tetapi di seluruh dunia, hal ini di karenakan dollar mengalami apresiasi terhadap hampir seluruh mata uang dunia. Selain itu dapat di identifikasikan dari sampel penelitian yaitu sektor infrastruktur dan sektor konstruksi di Indonesia yang melakukan kegiatan operasionalnya 
cenderung menggunakan bahan baku dari dalam negri, sehingga kegiatan perusahaaan cenderung tidak melakukan import dan cenderung tidak melakukan ekspor, sehingga menyebabkan kurs tidak terlalu berpengaruh terhadap perusahaan sektor infrastruktur dan sektor konstruksi.

Hasil penelitian ini mendukung penelitian Opod (2015) Novitasari (2017) Paizal (2017) yang menghasilkan kurs tidak berpengaruh dan tidak signifikan. Sehingga hipotesis 2 (H2) yang menyatakan bahwa kurs berpengaruh signifikan terhadap nilai perusahaan ditolak.

\section{Pengaruh DER terhadap Nilai Perusahaan}

Hasil penelitian ini menunjukkan bahwa Variabel DER tidak berpengaruh terhadap nilai perusahaan. Hal ini mengidentifikasikan bahwa Investor tidak terlalu memperhatikan tingkat penggunaan hutang perusahaan saat berinvestasi, sehingga tinggi atau rendahnya DER cenderung tidak mempengaruhi keputusan investor dalam melakukan investasi di pasar modal selama periode penelitian. Merujuk pada DER yang berfeluktuasi cenderung meningkat dan terdapat beberapa perusahaan sampel yang melakukan corporate action tetapi tidak mempengaruhi nilai perusahaan tersebut, dapat diasumsikan bahwa investor menangkap sinyal positif dari kebijakan pemerintah yang memfokuskan pembangunan infrastruktur dan deregulasi UU jasa konstruksi, sehingga investor tidak terlalu mempermasalahkan tingakt DER selama periode penelitian. Selain hal tersebut DER juga digunakan untuk menganalisis besarnya jaminan yang tersedia untuk kreditor, semakin rendah DER maka semakin baik bagi kreditor saat likuidasi, sehingga besarnya DER dapat mempengaruhi nilai perusahaan tersebut, hal tersebut bertolak belakang dengan hasil penelitian yang menujukan bahwa tingkat DER yang berfeluktuasi cenderung meningkat tidak mempengaruhi nilai perusahaan, sehingga dapat di identifikasikan karena sampel perusahaan sektor infrastruktur dan sektor konstruksi merupakan Badan Usaha Milik Negara (BUMN) dimana beberapa kebijakan pemerintah dapat menguntungkan perusahaan BUMN tersebut sehingga menyebabakan rasa aman bagi investor saat berinvestasi di perusahaan tersebut meskipun DER berfeluktuasi cenderung meningkat.

Hasil penelitian ini sesuai dengan Trade-off Theory dimana esensi trade off theory dalam struktur modal adalah menyeimbangkan manfaat dan pengorbanan yang timbul sebagai akibat penggunaan hutang. Jika manfaat lebih besar maka diperkenankan menggunakan tambahan hutang akan tetapi jika pengorbanan penggunaan hutang jauh lebih besar maka tambahan hutang tidak di perbolehkan, sehingga peningkatan hutang yang dilakukan oleh perusahaan tidak lagi mempengaruhi nilai perusahaan tersebut. Pada teori trade off menjelaskan bahwa sebelum mencapai titik maksimum, hutang akan lebih murah dari pada penjualan saham karena ada tax shield. Namun setelah mencapai titik maksimum, penggunaan hutang oleh perusahaan menjadi tidak menarik karena perusahaan harus menanggung biaya keagenan, biaya bunga, dan biaya kebangkrutan. Penelitian ini mendukung penelitain yang dilakukan oleh Uli (2009) Martdiyati,Ahmad \& Putri (2012) dan Sinaga \& Triaryati (2015) menujukan bahwa DER tidak berpengaruh terhadap nilai perusahaan. Sehingga hipotesis 3 (H3) yang menyatakan bahwa DER berpengaruh positif signifikan terhadap nilai perusahaan ditolak.

\section{Pengaruh ROE terhadap Nilai Perusahaan}

Hasil penelitian ini menunjukkan bahwa variabel ROE berpengaruh positif dan signifikan terhadap nilai perusahaan. Hal ini berarti semakin tinggi nilai profit yang didapat maka akan 
semakin tinggi nilai perusahaan. Karena profit yang tinggi akan memberikan indikasi prospek perusahaan yang baik sehingga dapat memicu investor ikut meningkatkan permintaan saham. Permintaan saham yang meningkat akan menyebabkan nilai perusahaan juga meningkat. Tingkat ROE yang tinggi dapat pula meningkatkan kepercayaan investor terhadap perusahaan tersebut, selain dari ROE yang tinggi, tingkat kepercayaan tersebut dapat diasumsikan dari investor yang menangkap sinyal positif dari kebijakan pemerintah yang memfokuskan pembangunan infrastruktur dan deregulasi UU jasa konstruksi, sehingga investor mengharapkan tingakat pengembalian yang tinggi selama periode penelitian

Penelitian ini sesuai dengan konsep signalling theory, dimana profitabilitas yang tinggi menunjukan prospek perusahaan yang baik sehingga investor akan merespon positif sinyal tersebut sehingga nilai perusahaan akan meningkat (Sujoko \& Soebintoro, 2007). Penelitian ini mendukung penelitian yang dilakukan Sinaga \& Triaryati (2015) dan Paizal (2017) yang mendapatkan ROE berpengaruh positif signifikan. Sehingga hipotesis 4 (H4) yang menyatakan bahwa ROE berpengaruh positif dan signifikan terhadap nilai perusahaan diterima.

\section{Variabel Yang Paling Dominan Terhadap Nilai Perusahaan}

Variabel yang mempunyai pengaruh paling dominan terhadap nilai perusahaan adalah ROE. Hal ini menunjukkan di antara variabel-variabel penelitian, ROE yang paling mempengaruhi nilai perusahaan di mata investor untuk membeli saham tersebut. Karena profit yang tinggi akan memberikan indikasi prospek perusahaan yang baik sehingga dapat memicu investor ikut meningkatkan permintaan saham. Permintaan saham yang meningkat akan menyebabkan nilai perusahaan juga meningkat.

Penelitian ini mendukung penelitian yang dilakukan Haryanto (2011), yang mendapati variabel ROE mempunyai kontribusi yang paling domiann terhadap harga saham yang mencerminkan nilai perusahaan, begitu pula dengan penelitian lubis, dkk (2017) mendapati nilai probabilitas terbesar adalah ROE jika dibandingkan dengan variabel independen lainnya, sehingga hipotesis 5 (H5) yang menyatakan bahwa ROE yang paling dominan terhadap nilai perusahaan diterima.

\section{KESIMPULAN}

Berdasarkan hasil analisis dan pembahasan yang telah diuraikan sebelumnya maka dapat ditarik kesimpulan sebagai berikut:

1. Variabel inflasi tidak berpengaruh terhadap nilai perusahaan. Hal ini menunjukkan bahwa tingkat inflasi di Indonesia selama periode penelitian tidak memberikan pengaruh terhadap nilai perusahaan, berarti investor pada periode penelitian tidak mempermasalahkan inflasi saat melakukan investasi.

2. Variabel kurs tidak berpengaruh terhadap nilai perusahaan. Hal ini menunjukkan bahwa apresiasi atau depresiasinya Rp/US\$ tidak berpengaruh terhadap nilai perusahaan. Merujuk pada tingkat pertumbuhan kurs rupiah terhadap dollar selama periode 2015 sampai 2017 yang berfeluktuasi cenderung meningkat, tetapi hasil penelitian tidak mempengaruhi nilai perusahaan, menunjukan bahwa investor mengganggap pertumbuhan kurs rupiah terhadap dollar masih di anggap wajar, dikarenakan hal tersebut tidak hanya terjadi di Indonesia, tetapi di seluruh dunia, hal ini di karenakan dollar mengalami apresiasi terhadap hampir seluruh mata uang dunia. 
3. Variabel DER tidak berpengaruh terhadap nilai perusahaan. Penelitian ini selaras dengan teori trade off yang menjelaskan bahwa sebelum mencapai titik maksimum, hutang akan lebih murah dari pada penjualan saham karena ada tax shield. Namun setelah mencapai titik maksimum, penggunaan hutang oleh perusahaan menjadi tidak menarik karena perusahaan harus menanggung biaya keagenan, biaya bunga, dan biaya kebangkrutan. Hal tersebut yang mengidentifikasikan DER tidak berpengaruh terhadap nilai perusahaan.

4. Variabel ROE berpengaruh positif dan signifikan terhadap nilai perusahaan. Hal ini berarti semakin tinggi nilai profit yang didapat maka akan semakin tinggi nilai perusahaan. Karena profit yang tinggi akan memberikan indikasi prospek perusahaan yang baik sehingga dapat memicu investor ikut meningkatkan permintaan saham. Hal ini selaras dengan signalling theory, dimana profitabilitas yang tinggi menunjukan prospek perusahaan yang baik sehingga investor akan merespon positif sinyal tersebut sehingga nilai perusahaan akan meningkat

5. Variabel yang mempunyai pengaruh paling dominan terhadap nilai perusahaan adalah ROE. Hal ini menunjukkan di antara variabel-variabel penelitian, ROE yang paling mempengaruhi keputusan investor untuk membeli saham prtusahaan tersebut.

\section{SARAN}

1. Bagi investor, Diharapkan hasil penelitian ini dapat memberikan informasi mengenai faktor fundamental makro dan mikro yang memengaruhi nilai perusahaan pada sektor infrastruktur dan sektor konstruksi pada tahun 2015 sampai 2017 yaitu Return On Equity (ROE).

2. Bagi Perusahaan, Diharapkan hasil penelitian ini dapat membantu perusahaan dalam mempertimbangkan pengambilan keputusan yang lebih baik lagi dalam meningkatkan Return On Equity (ROE), dan memperhatikan keputusan pendanaan agar dapat menarik bagi investor sehingga dapat meningkatkan nilai perusahaan.

3. Bagi peneliti selanjutnya dapat sebagai rujukan saat melakukan penelitian tentang faktor fundamental makro dan mikor terhadap nilai perusahaan dan dapat mengembangakan penelitian ini dengan menggunakan proksi fundamental makro dan mikro yang lain dan proksi dari nilai perusahaan yang lain.

\section{DAFTAR PUSTAKA}

Arifin, Ali. 2004. Membaca Saham. Cetakan Kedua. Andi, Jakarta.

. 2007. Membaca Saham Panduan Dasar Seni Berinvestasi. CV Andi Offset, Yogyakarta.

Arvianto, R. A. Sabi., Suhadak \& Topowijono. 2014. “ Pengaruh Faktor Fundamental Makro Dan Mikro Terhadap Nilai Perusahaan (Studi pada Saham Perusahaan Sektor Perdagangan, Jasa, dan Investasi yang Terdaftar di BEI Periode 2010-2012)". Jurnal Administrasi Bisnis (JAB) Vol. 13 No. 1 Agustus 2014.

Elzadora, Rida. 2009. "Pengaruh Variabel Makro dan Mikro Ekonomiterhadap Harga Saham Perusahaan (Studi pada indeks LQ45 di Bursa Efek Indonesia periode 20032007)". Skripsi. Universitas Sebelas Maret, Surakarta.

Fahmi, Irham. 2006. Analisis Investasi. Aditama. Bandung. 
Fahmi, Irham dan Lavianti, Yovi. 2009. Teori Portofolio dan Analisis Investasi. Alfabeta, Bandung.

Fahmi,Irham. 2012. Analisis kinerja keuangan. Alfabeta. Bandung.

2013. Analisis Laporan Keuangan.:Alfabeta. Bandung.

Hardaningtyas, Prihati. 2014. “Pengaruh Faktor Fundamental Mikro Makro Terhadap Harga Saham Perusahaan Semen Go Public". Jurnal Ilmu \& Riset Manajemen Vol. 3 No. 10 (2014).

Haryanto, Sugeng.2011. “Karakteristik Perusahaan dan Risiko Bisnis Terhadap Harga Saham pada Industri Otomotif di Bursa Efek Indonesia". MODERNISASI, Volume 7, Nomor 2, Juni 2011.

Ismanidar, Nur. 2017. "Pengaruh Faktor Fundamental Makro dan Mikro Terhadap Return Saham(Studi Pada Perusahaan Tambang Yang Terdaftar Di Bursa Efek Indonesia)". JII Vol. 2 No. 1 April 2017.

Kasmir. 2012. Bank dan Lembaga Keuangan Lainya. Jakarta:Rajawali Pers. 2013. Analisis Laporan Keuangan. PT Rajagrafindo Persada, Jakarta.

Lubis, Ignatius Leonardus., Sinaga, Bonar M., \& Sasongko, Hendro.2017. "Pengaruh Profitabilitas, Sruktur Modal, dan Likuiditas Terhadap Nilai Perusahaan". Jurnal Aplikasi Bisnis dan Manajemen, Vol. 3 No. 3, September 2017. ISSN: 25285149.EISSN: 2460-7819.

Mardiyati,Umi.,Ahmad,Gatot Nazir.,\&Putrid,Ria.2012. “Pengaruh Kebijakan Dividen, Kebijakan Hutang dan Profitabilitas Terhadap Nilai Perusahaan Manufaktur yang Terdaftar di Bursa Efek Indonesia (BEI) Periode 2005-2010". Jurnal Riset Manajemen Sains Indonesia (JRMSI) | Vol. 3, No. 1, 2012.

Novitasari, Rini .2017.“Pengaruh Faktor Fundamental Mikro Dan Makro Terhadapnilai Perusahaan”.Jurnal. Sekolah Tinggi Ilmu Ekonomi Indonesia Surabaya.

Opod, Chrisna Riane. 2015. “Analisis Pengaruh Faktor - Faktor Fundamental Makroekonomi Terhadap Kinerja Keuangan Perusahaan Serta Nilai Perusahaan (Studi Kasus Pada Perusahaan Perbankan yang Terdaftar di BEI Periode 2009 - 2013)". Jurnal Riset Bisnis dan Manajemen Vol.3,No.2, 2015:127-140.

Paizal, Muhammad.2017. “Pengaruh Makro Ekonomi Dan Mikro Perusahaan Terhadap Harga Saham Perusahaan Sub Sektor Otomotif yang Terdaftar di Bursa Efek Indonesia Periode 2012-2015".Jurnal.

Rachman, Alwi Abdul \& Sutrisno .2013. "Analisis Pengaruh Faktor-Faktor Fundamental Terhadap Harga Saham Perusahaan Manuaktur”. ISBN: 978 $-979-636-147-2$.

Sinaga, Ari Kristanti \& Triaryati, Nyoman. 2015. “Pengaruh Faktor Fundamental Dan Ekonomi Makro Terhadap Harga Saham".jurnal. Fakultas Ekonomi dan Bisnis Universitas Udayana (FEBUnud), Bali, Indonesia.

Sartono, Agus. 2010. Manajemen Keuangan Teori dan Aplikasi (4th ed.). Yogyakarta: BPFE

Susilo, Bambang. 2009. Pasar Modal Mekanisme Perdagangan Saham, Analisis Skuritas, dan Strategi Investasi Di BEI.Yogyakarta: UPP STIM YKPN.

Sugiyono. 2012. Memahami Penelitian Kualitatif. Bandung:Alfabeta.

.2013. Metode Penelitian Kuantitatif Kualitatif Dan R\&D. Bandung:Alfabeta.

Sujoko dan Ugy Soebiantoro. 2007. Pengaruh Struktur Kepemilikan Saham, Leverage, Faktor Intern dan Faktor Ekstern Terhadap Nilai Perusahaan (Studi Empiris Pada Perusahaan Manufaktur Dan Non Manufaktur di Bursa Efek Jakarta). Jurnal Manajemen dan Kewirausahaan. Vol. 9, No. 1, Hal: 41-48. 
Sudiyatno, Bambang. 2010. Peran Kinerja Perusahaan Dalam Menentukan Pengaruh Faktor Fundamental Makroekonomi, Risiko Sistematis, Dan Kebijakan Perusahaan Terhadap Nilai Perusahaan (Studi Empirik Pada Perusahaan Manufaktur di Bursa Efek Indonesia). DISERTASI. Universitas Diponegoro, Semarang.

Tandelilin, Eduardus. 2010. Analisis Investasi dan Manajemen Portofolio. Edisi Ketujuh. Kanisius. Yogyakarta

Uli, Annissa Yunita. 2009. “Analisis Pengaruh Faktor Fundamental Dan Risiko Sistematik Terhadap Harga Saham Pada Perusahaan Sektor Industri Barang Konsumsi di BEI”. Jurusan Akuntansi, Fakultas Ekonomi, Universitas Gunadarma.

www.katadata.co.id, diakses 15 Desember 2017

www.economy.okezone.com, diakses 15 Desember 2017

www.bps.go.id, diakses 26 Januari 2018

www.finance.detik.com, diakses 15 Desember 2017

www.idx.co.id, diakses 9 Januari 2018. 